\title{
Why Britain does not need a Minister for Science By Margaret Thatcher
}

Ian Lloyd, a Conservative MP, was the chairman of the subcormmittee on science of the Commons Select Committee on Science and Technology. We publish excerpts from an exchange between him and Margaret Thatcher on science policy

Dear Prime Minister, I hope you will not mind my sending you two documents which bear on the exchange of views on science policy administration between us at Question Time on Thursday 12 July. The first is an article by Judy Redfearn in Nature (12 July, 98-99) on the role now being filled by Pierre Aigrain in France. The second is a guest leader in New Scientist which I have been asked to write (2 August, 346).

Pierre Aigrain was Chairman of the Committee on Information Technology in the EEC which now bears his name. He has made a distingushed and forceful contribution to science policy. The role which he now discharges in the French government is precisely what I had in mind when putting my question. Apart from yourself, no Minister, to my knowledge, has the same function here. There is no national "science budget", only a series of departmental science budgets . . . There is, therefore, no overall view and such a view is urgently required.

Aigrain has commissioned and is publishing a report on the organisation of French science and the resource allocation policy behind it which he claims, I believe rightly, to be unique. I do not know of any report which is as comprehensive as "L'état des sciences et des techniques francaises" and I am not aware of any document in the UK which provides information from which government, or anyone else interested in science policy, could draw conclusions similar to those set out in the inset article on page 99 of Nature.

I hold a strong conviction that we need such a Minister, such an allocation of responsibility, and that a similar report on the organisation and effectiveness of scientific research within the UK is required. I do not believe that a general sympathy for the importance of science and technology within the existing departmental structure - important though it may be - is a sufficient condition for the successful appliciation of science in the United Kingdom in today's circumstances ..

My other reason for raising this issue is the profound dismay which I believe we have caused by a failure to re-establish the Select Committee on Science and Technology. I know that the Parliamentary and Scientific Committee is most concerned about this and that this lies behind the decision of the House of Lords to set up their own Select Committee on
Science and Technology which they hope eventually to broaden into a joint committee of both Houses. While this is no substitute for the Commons committee, it will salvage something from the wreck and I strongly support their Lordship's initiative. Their contribution of scientific expertise will be most important and it is conceivable that such a joint committee, provided it has the government's suport, may well develop into an organisation around which a thorough and wide ranging review of national policy and performance in the field of science and technology policy might be built . .

Dear Ian, You will remember that your point was extensively debated here in the early $1970 \mathrm{~s}$. In fact there was then a more centralised science budget than there is now . . . But the centralised system was not considered satisfactory.

Our system was given its present shape by the 1972 White Paper "Framework for Government Research and Development" (Cmnd 5046). . . These arrangements were reviewed by the last Government. The result of the review was published in March this year as a White Paper (Cmnd 7499).

Our system recognised that Government-sponsored applied science and technology is not an end in itself, but a means of helping to achieve the Government's policies and objectives. It follows that policy on applied science and technology in any sector should be associated with policy on investment, human resources, market needs and other factors, and should therefore be the concern of the Minister responsible for overall policy in that sector. But there is one sector - fundamental research where there is no close link between research and policy. For that, it makes sense to entrust responsibility to the Minister who is responsible for those institutions of higher education where much of this type of research is done . . .

If we went over to a centralised system with a separate Minister for Science with his own department we would have to accept the disadvantage of divorcing those responsible for applied $\mathrm{R}$ and $\mathrm{D}$ from those concerned with formulating and implementing the policies to which their $\mathrm{R}$ and $D$ related. In fundamental science we would have an unwelcome division between responsibility for higher education and for the scientific community supported by the Research Councils.

At present we have machinery to ensure

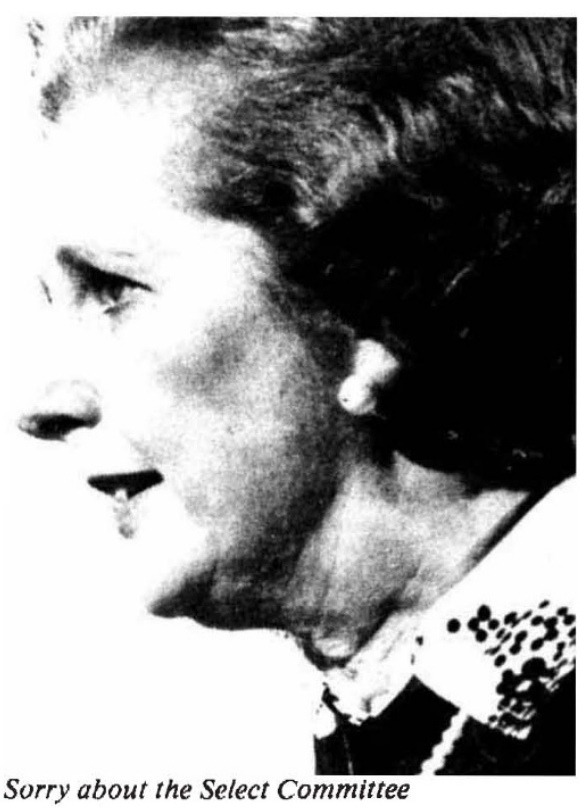

that there is no harmful overlap between Departmental $\mathrm{R}$ and $\mathrm{D}$ programmes and policies, that no gaps arise, that policy questions with a major scientific or technological content are considered inderpartmentally; where this is necessary and that the quality and direction of $\mathbf{R}$ and $\mathrm{D}$ in any area, or over all areas, can be assessed. Since 1976 a committee of permanent secretaries and chief scientists has provided interdepartmental coordination of science and technology matters at high official level; and the Central Policy Review Staff play an active part in the overview aspect

I note your view that we need for Britain a report on the organisation of our science and the resources that go into it on the lines of what the French are doing. I should like to consider in due course whether such a report would be valuable .... The Research Councils and several Departments publish annual reports on the $\mathrm{R}$ and $\mathrm{D}$, and it may take some time to digest the implications of the reduction in public expenditure to which we are committed. But I am quite sure that we do not need a Minister for Science to prepare such a report ...

I am not saying that our present system should never be adapted. On the contrary, I intend to keep an eye on how it is and modify it as may be required. I recognised, for example, that under the present arrangements issues may arise which straddle the responsibility of several Ministers to such an extent that it would not be sensible to ask one of them to take the lead. In such a case I would myself play a coordinating role. .

Personally I was very sorry that the House decided not to re-establish the former Select Committee on Science and Technology. I thought it did valuable work and was complementary to the role of departments. But you and I were overruled by the vote - however much we both regret it. 